\title{
STRATEGI MASYARAKAT ETNIS TIONGHOA DAN MELAYU BANGKA DALAM MEMBANGUN INTERAKSI SOSIAL UNTUK MEMPERKUAT KESATUAN BANGSA
}

\author{
Melia Seti Satya, Bunyamin Maftuh \\ SMPN 2 Pemali, Sungailiat, email: meliasetisatya@gmail.com
}

\begin{abstract}
ABSTRAK
Penelitian ini mengkaji strategi yang dilakukan masyarakat etnis Tionghoa dan Melayu Bangka dalam membangun interaksi sosial untuk memperkuat kesatuan bangsa. Penelitian menggunakan pendekatan kualitatif dengan metode etnografi. Teknik pengumpulan data dalam menghimpun data dan informasi yakni wawancara, observasi, dan dokumentasi. Subjek penelitian ini terdiri atas tokoh adat Melayu dan Tionghoa Bangka, tokoh pemerintahan Kabupaten Bangka, masyarakat etnis Tionghoa dan Melayu Bangka, dan guru sosiologi di sekolah multietnis. Hasil penelitian mengungkapkan kesatuan masyarakat Kabupaten Bangka sebagai bagian dari bangsa Indonesia sudah terjadi sejak lama dan interaksi sosial masyarakat etnis Tionghoa dan Melayu Bangka berjalan dengan alamiah dan tanpa paksaan. Strategi masyarakat etnis Tionghoa dan Melayu Bangka dalam interaksi sosial yakni dengan mengakui kesetaraan antara kedua etnis, sesuai dengan semboyan fan ngin, to ngin jit jong, artinya semua etnis setara. Rekomendasi penelitian kepada pemerintah Kabupaten Bangka dan masyarakat etnis Tionghoa dan Melayu untuk mempertahankan kerukunan dan mengantisipasi kendala dalam interaksi sosial masyarakat etnis Tionghoa dan Melayu Bangka untuk memperkuat kesatuan bangsa.
\end{abstract}

Kata kunci : interaksi sosial, Etnis Tionghoa, Etnis Melayu Bangka, kesatuan bangsa.

\section{PENDAHULUAN}

Indonesia telah menjadi negara yang multietnik sejak masa kolonial, dengan membagi stratifikasi sosial dalam tiga golongan, yaitu; ras kulit putih (Belanda) dengan status kelas sosial yang paling tinggi, ras timur asing atau kulit kuning (Arab, Cina, India) sebagai kelas sosial kedua, dan ras pribumi sebagai kelas sosial yang paling rendah. Geertz dalam Anshory (2008, hlm. 3) bahwa Indonesia begitu kompleks sehingga sulit memaparkan keseluruhan Indonesia secara persis, karena Indonesia bukan hanya multietnis (Jawa, Batak, Bugis, Flores, Bali dan sebagainya) melainkan juga dipengaruhi oleh budaya multimental yang dibawa negara lain (India, Cina, Belanda, Portugis, Hinduisme, Budhaisme, Konfisianisme, Islam, Kristen, Kapitalis, dsb.). Indonesia terdiri dari sejumlah ras dengan jumlah, makna, dan karakter yang berbeda-beda yang memiliki sejarah, ideologi, agama, tersusun sebagai sebuah struktur ekonomi dan politik bersama.
Beberapa keanekaragaman Indonesia dalam kondisi kompleksitas ini tentu memiliki nilai-nilai yang baik yang tetap hidup dan dianut hingga saat ini. Nilai-nilai ini mengandung pedoman hidup, norma-norma, etika, dan estetika. Hal tersebut sangat berpengaruh pada kelangsungan hidup dan martabat bangsa apabila bangsa Indonesia mampu memanfaatkannya dengan baik. Kekayaan keanekaragaman budaya bangsa sebagai dasar perwujudan dari pembangunan karakter bangsa, bangsa yang bermartabat, bermoral, ramah tamah, cinta lingkungan, adil, hidup rukun dan toleransi dengan nasionalisme tinggi yang merupakan harapan dari seluruh warga negara.

Salah satu kompleksnya Indonesia secara horizontal adanya keberagaman etnis. Etnisetnis di Indonesia tersebar dari wilayah Sabang hingga Merauke. Terdapat etnis yang memang berasal dari indonesia sebagai etnis pribumi, maupun etnis yang berasal dari keturunan etnis bangsa lain yang telah menetap di Indonesia 
secara turun temurun dan menjadi bagian dari warga negara Indonesia, salah satunya adalah etnis Tionghoa. Etnis Tionghoa di Indonesia merupakan hasil dari keturunan bangsa Cina yang merantau ke Indonesia kemudian menetap dan memiliki keturunan, baik dengan sesama orang Cina, maupun dengan melakukan pernikahan campur dengan etnis pribumi.

Suryadinata (2002, hlm. 2) menyatakan bahwa penduduk Tionghoa terdiri dari kelompok-kelompok. Kelompok paling umum ialah kaum peranakan yang kebudayaannya sudah mengindonesia dan kaum totok yang masih tebal ketionghoaannya. Disebut peranakan adalah : a. Mereka yang dilahirkan dari seorang ibu dan ayah dari Cina dan lahir di Indonesia, b. Mereka yang lahir dari perkawinan campuran yaitu laki-laki Tionghoa dan wanita pribumi dan disahkan serta didaftarkan sebagai anak sahnya, c. Mereka yang dilahirkan dengan perkawinan campuran antara ayah pribumi dan ibu Tionghoa dan mendapatkan pendidikan di dalam lingkungan Tionghoa.

Cina totok adalah kaum Cina lanjut usia yang kecinaannya masih sangat kental. Secara umum etnik Cina totok di Indonesia membuat lingkungannya sendiri untuk dapat hidup secara "eksklusif" dengan tetap mempertahankan kebudayaan atau tradisi leluhur (Revida, 2006, hlm. 25-26). Berdasarkan pengamatan sementara penulis, walaupun kaum Cina totok telah hidup di Indonesia, namun mereka sangat mempertahankan tradisi leluhur. Mereka tetap menggunakan bahasa Cina dalam berkomunikasi. Selain itu, membatasi pergaulan dengan orang pribumi. Hal ini dikarenakan banyak perbedaan cara pandang dan tradisi dalam kehidupan sehari-hari. Golongan Tionghoa peranakan merupakan golongan yang kebudayaannya sudah tercampur dengan kebudayaan lokal. Sedangkan orang totok masih sangat memegang tradisi dan adat kehidupan Cina, ini terlibat pada agama dan kepercayaan, gaya hidup, kebudayaan dan orientasi hidup. Seiring dengan perkembangan zaman, kaum peranakan semakin banyak, dan kaum totok semakin berkurang. Kaum peranakan lebih terbuka dalam menerima perubahan, baik perubahan budaya, agama, maupun bahasa.

Dinamika posisi identitas etnis Tionghoa sebenarnya terkait perlakuan yang diterima dari pihak penguasa (Eriyanti, 2006, hlm. 29). Setelah Indonesia merdeka, banyak etnis Tionghoa yang menjadi warga negara Indonesia. Berdasarkan informasi yang didapatkan dari warga Tionghoa yang telah lama menetap di Bangka, yakni Bong Kun Chai (kepala desa Rebo) pada awal kemerdekaan, orang-orang Tionghoa sulit untuk mengurus persuratan yang berhubungan dengan instansi pemerintah, misalnya akta lahir, KTP, surat nikah, dan sebagainya. Butuh waktu yang lama dan biaya yang besar untuk membuat akta lahir dan KTP. Dalam hal mata pencaharian, warga Tionghoa lebih memilih untuk menjadi pedagang, berkebun atau kuli tambang inkonvensional timah dan hingga saat ini pun jarang sekali ada orang Tionghoa yang menjadi Pegawai Negeri Sipil. Hal tersebut dikarenakan sulitnya warga Tionghoa pada awal masa kemerdekaan Indonesia berhubungan dengan birokrasi pemerintah.

Untuk mengantisipasi hal tersebut, etnis Tionghoa pun banyak yang terjun ke kancah politik. Mereka mendirikan beberapa organisasi politik untuk melindungi status dan kepentingan mereka di Indonesia. Chung Hwa Hwee (1948), Persatuan Demokrat Tionghoa Indonesia (PDTI) tahun 1954, Badan Permusyawaratan Kewarganegaraan Indonesia (Baperki) adalah organisasi-organisasi yang dibentuk untuk memperjuangkan status mereka yang telah sah menjadi warga negara Indonesia. Organisasi politik tersebut menjadi wadah bagi warga etnis Tionghoa untuk ikut berpartisipasi dalam mengeluarkan aspirasi mereka sebagai warga negara Indonesia yang memiliki hak berpolitik yang sama dengan warga Indonesia pribumi. 
Etnis Tionghoa yang telah lama menetap di Indonesia dan menikah dengan pribumi, serta telah resmi menjadi warga negara Indonesia, masih mendapatkan masalah mengenai status keberadaan mereka di Indonesia. Hal ini dikarenakan identitas etnis Tionghoa yang masih dipertanyakan. Selain itu, kemajemukan etnis di Indonesia memang rentan menimbulkan konflik sosial. Konflik antar etnis dengan etnis Tionghoa dapat dilihat dari tabel 1.

Tabel 1 Konflik Etnis Tionghoa di Indonesia

\begin{tabular}{|c|c|}
\hline Periode & Konflik \\
\hline $\begin{array}{ll}\text { Awal abad } \\
\text { ke-18 }\end{array}$ & $\begin{array}{l}\text { Peristiwa "Geger Pecinan" yang terjadi di Batavia dan Semarang, dimana VOC } \\
\text { melakukan deportasi dan pembunuhan terhadap etnis Tionghoa. }\end{array}$ \\
\hline 1912-1918 & $\begin{array}{l}\text { Kerusuhan Tionghoa dipercaya memiliki keterkaitan dengan kegiatan-kegiatan serikat } \\
\text { Indonesia yang berkonflik dengan etnis Tionghoa yang terjadi di Surakarta dan } \\
\text { Surabaya. }\end{array}$ \\
\hline 1918 & $\begin{array}{l}\text { Kerusuhan terjadi di Kudus. Kerusuhan ini terjadi akibat pertentangan kepentingan } \\
\text { antara pengusaha Tionghoa dengan para pedagang pribumi. Akibat dari kerusuhan } \\
\text { tersebut beberapa orang Tionghoa terbunuh dan mereka juga banyak mengalami luka- } \\
\text { luka. Selain korban jiwa, rumah-rumah warga Tionghoa juga banyak yang habis } \\
\text { dibakar. }\end{array}$ \\
\hline 1997-2000 & $\begin{array}{l}\text { Peristiwa "Natal Kelabu" : Tasikmalaya, Rengasdengklok, Pasuruan, probolinggo, } \\
\text { Pekalongan, Situbondo (warsilah, } 2000: 22 \text { ). Kerusuhan ini juga melibatkan etnis } \\
\text { Tionghoa sebagai korban. }\end{array}$ \\
\hline $\begin{array}{l}12-14 \\
\text { Mei1998 }\end{array}$ & $\begin{array}{l}\text { Kerusuhan Mei } 1998 \text { yang terjadi di Jakarta, Surakarta, dan dimana etnis Tionghoa yang } \\
\text { dijadikan target serangan sebagai akibat sentimen primordial yang mengakar. }\end{array}$ \\
\hline
\end{tabular}

(Sumber : Ishardanti, 2011).

Etnis Tionghoa terdapat di beberapa wilayah di Indonesia, termasuk di kepulauan Bangka. Mereka sudah berdomisili di beberapa wilayah tersebut dari masa nenek moyang mereka. Kepulauan Bangka memiliki penduduk etnis Tionghoa yang cukup banyak. Heidhues (2008, hlm. 44) menyatakan bahwa laporan dari Residen van Olden menyebutkan pada tahun 1849 dimulai imigrasi etnis Tionghoa ke pulau Bangka dari tempat asal mereka di Guangdong, Tiongkok. Awal kedatangan mereka ke pulau Bangka sebagai pekerja atau buruh pertambangan timah. Pada saat itu terdapat 200 lebih pertambangan yang beroperasi. Secara keseluruhan terdapat sekitar 9.000 orang Tionghoa di pulau Bangka.

Lahirnya UU No. 12 Tahun 2006 tentang Kewarganegaraan dan UU No. 40 Tahun 2008 Tentang Penghapusan Diskriminasi Ras dan Etnis yang merupakan landasan dari upaya dan komitmen pemerintah untuk memberikan perlindungan, kepastian, dan kesamaan kedudukan di dalam hukum pada semua warga negara untuk hidup bebas dari diskriminasi ras dan etnis. Masyarakat Tionghoa di Bangka dewasa ini sudah lebih leluasa melaksanakan aktivitas yang berkaitan dengan kehidupan mereka sebagai warga negara, misalnya membuat Kartu Tanda Penduduk, melakukan pemilihan umum, beribadah sesuai kepercayaan, dan menyekolahkan anak-anak mereka di sekolah negeri. Sebagai akibat dari pergaulan dan interaksi sosial yang cukup lama antara masyarakat Tionghoa dengan kelompok etnis pribumi, dewasa ini masyarakat Tionghoa sudah banyak yang menjadi pemeluk agama-agama yang diakui negara seperti Budha, Islam, Kristen Protestan dan Katolik. Orang-orang Tionghoa di Bangka seperti orang-orang Tionghoa yang ada di daerah-daerah lain di Indonesia, pada umumnya melaksanakan ritualritual yang berkaitan dengan pemujaan Budha dan Kong $\mathrm{Fu}$ Chu. Hal ini diperkuat dengan dukungan yang diberikan oleh Abdurrachman Wahid sebagai Presiden Indonesia ke 4 (19992001) yang memberikan kebebasan bagi warga 
Tionghoa untuk mengekspresikan diri dan mengesahkan Kong $\mathrm{Hu} \mathrm{Cu}$ sebagai aliran kepercayaan yang dianut oleh etnis Tionghoa menjadi agama yang diakui di Indonesia.

Selain masyarakat etnis Tionghoa yang telah lama menetap, pulau Bangka didiami pula oleh orang-orang pribumi. Orang pribumi muslim di Bangka disebut sebagai orang Melayu. Leluhur etnis Melayu berasal semenanjung Malaya. Ali dalam Selayang Pandang Kabupaten Bangka (2000, hlm. 3-4) menyatakan awal kedatangan leluhur etnis Melayu di pulau Bangka adalah pada saat raja Sultan Johor yang merupakan raja kerajaan Sriwijaya saat itu mengirimkan pasukannya dan kemudian memberantas para bajak laut yang ada di pulau Bangka. Setelah berhasil menumpas para bajak laut di pulau Bangka, Sultan Johar mengirimkan rakyat Sriwijaya yang menetap di Semenanjung Malaya untuk menetap di pulau Bangka. Hal ini merupakan awal mula masuknya etnis Melayu dan Islam ke Bangka. Perkembangan Islam di Bangka terpusat di Sungailiat, Pangkal Pinang, Belinyu, Puding, menyebar hingga ke Kotawaringin dan Bangkakota. Pada awalnya penduduk asli Bangka belum memeluk suatu agama, mereka memiliki kepercayaan terhadap roh nenek moyang. Setelah kedatangan etnis Melayu yang beragama Islam dan menetap di Bangka turun temurun, Islam semakin menyebar dan menjadi agama mayoritas di sana. Orang asli Bangka yang sudah memeluk Islam disebut sebagai orang "lah". "lah" memiliki arti sudah. Jadi orang "lah" adalah orang Bangka yang sudah beragama Islam. Orang yang sudah beragama Islam disebut pula sebagai orang Melayu, hal ini dikarenakan agama mereka yang sama dengan etnis Melayu yang berasal dari Semenanjung Malaya dan menjadikan mereka berbeda dengan orang asli Bangka yang belum masuk Islam atau biasa disebut dengan orang "lum".

Selama ratusan tahun, pribumi Melayu dan etnis Tionghoa hidup rukun dan toleran.
Tidak ada kota di Indonesia yang penulisan nama jalannya menggunakan tiga bahasa selain Sungailiat, ibukota Kabupaten Bangka, Provinsi Kepulauan Bangka Belitung. Di sana, setiap papan nama jalan ditulis menggunakan bahasa Indonesia, yang letaknya paling atas, lalu bahasa Arab dan bahasa Mandarin. Kebijakan yang diterapkan sejak tahun 2006 tersebut sengaja dilakukan pemerintah setempat guna menunjukkan dan memberi pesan kepada masyarakat luas bahwa daerah itu dihuni warga berbagai suku dan agama, yang semuanya memiliki posisi setara.

Maftuh dan Sapriya menyatakan bahwa Pendidikan Kewarganegaraan mempunyai objek studi yaitu warga negara dalam hubungannya dengan organisasi kemasyarakatan sosial, ekonomi, agama, kebudayaan, dan negara. Tujuan negara mengembangkan Pendidikan Kewarganegaraan (PKn) adalah agar setiap warga negara menjadi warga negara yang baik (to be good citizenship) yakni warga negara yang memiliki kecerdasan (civic intelligence), baik intelektual, emosional, sosial, maupun spiritual; memiliki rasa bangga dan tanggung jawab (civic responsibility); dan mampu berpartisipasi dalam kehidupan bermasyarakat dan bernegara (civic participation) agar tumbuh rasa kebangsaan dan cinta tanah air (2005, hlm. 319-320).

Etnis Tionghoa dan Melayu Bangka merupakan bagian dari warga negara yang memiliki hak dan kewajiban yang sama terhadap negara. Pendidikan Kewarganegaraan memiliki peran penting dalam membentuk karakter dan kesadaran warga negara. Membangun karakter bangsa (national character building) adalah hal yang sangat penting untuk menjaga dan memelihara eksistensi suatu bangsa dan negara. Sebagai bangsa yang memiliki falsafah/pandangan hidup yang diyakini kebenarannya sampai saat ini, bangsa Indonesia mulai menyadari pentingnya akhlak mulia. Untuk menumbuhkan kembali jati 
diri kader bangsa yang berkarakter sebagai kader pemimpin nasional adalah dengan menyiapkan sumber daya manusia (SDM) yang unggul guna tumbuh kualitas pemimpin yang berorientasi kepada karya bukan berorientasi kepada tumbuhnya pemimpin nasional yang mengiklankan diri (Widodo, 2010, hlm. 142).

Dari pemaparan di atas, penulis tertarik untuk mengetahui bagaimana interaksi sosial yang dilakukan oleh etnis Tionghoa dan Melayu pribumi Bangka. Tidak hanya itu, penulis ingin mengetahui bagaimana strategi etnis Tionghoa dalam berinterksi dengan Melayu pribumi sehingga mereka dapat diterima dengan baik di dalam hubungan sebagai warga negara yang memiliki hak dan kewajiban yang sama.

\section{METODE PENELITIAN}

Penelitian ini menggunakan pendekatan kualitatif dengan metode etnografi. Penggunaan pendekatan etnografi dilakukan untuk mendeskripsikan fenomena interaksi antar etnis yang diperoleh dari partisipan penelitian secara alamiah. Fenomena adalah berkenaan dengan penegtahuan, nilai-nilai, kayakinan-keyakinan, norma-norma, tradisi-tradisi atau kebiasaankebiasaan, simbol-simbol, bahasa, dan praktek kehidupan sehari-hari. Teknik pengumpulan data melalui wawancara, observasi, dan dokumentasi. Partisipan penelitian ini terdiri atas tokoh adat Melayu dan Tionghoa Bangka (Tokoh adat Melayu : H. Husein Djais, S.Ag (HD), tokoh adat Tionghoa: Bong Fui (BF), tokoh pemerintah Kabupaten Bangka (Asisten Pemerintahan dan Kesejahteraan Rakyat : $\mathrm{H}$. Haryanto, SH (H), Kepala Seksi Sejarah dan Purbakala Dinas Kebudayaan dan Pariwisata : CH. Sufian SP, S.Hum (CS), Lurah Desa Rebo : Bhun Khun Chai (BKC), masyarakat etnis Tionghoa dan Melayu Bangka (masyarakat etnis Melayu : dr. Deni Kurniadi (DK), Nova Ariyani, SPd (NA), masyarakat etnis Tionghoa : Cong Ju Ni (CJN) dan guru Sosiologi sekolah multietnis (Derry Nodyanto, S.Pd(DN)).

\section{HASIL DAN PEMBAHASAN}

Sebagai mahluk sosial, manusia memerlukan interaksi dengan orang lain. Interaksi sosial yang dilakukan oleh etnis Tionghoa dan Melayu Bangka terjadi untuk memenuhi kebutuhan hidup. Interaksi terjadi di berbagai bidang, diantaranya interaksi di bidang ekonomi, politik, agama, pendidikan, sosial, dan budaya. Etnis Melayu adalah etnis mayoritas. Oleh karena itu interkasi yang terjadi di berbagai bidang ini banyak dipengaruhi oleh kebudayaan Melayu.

Berdasarkan temuan dari hasil wawancara dan observasi penulis, interaksi yang terjadi di bidang ekonomi antara etnis Tionghoa dan Melayu adalah perdagangan. Orang Tionghoa banyak yang berbisnis dengan berdagang. Selain berbisnis dagang, etnis Tionghoa pun ada yang menjadi petani, berkebun, buruh, peternak, maupun nelayan. Ada pula beberapa orang Tionghoa yang menjadi PNS, walaupun sangat jarang sekali ada orang Tionghoa menjadi PNS. Adanya orang Tionghoa yang menjadi PNS merupakan bukti bahwa tidak ada diskriminasi etnis untuk perekrutan pegawai negara. Adanya kemitraan antara etnis Tionghoa dan Melayu dalam bidang ekonomi. Etnis Tionghoa yang memiliki modal (uang) bermitra dengan orang Melayu sebagai pemasok bahan baku atau tenaga kerja. Banyak orang Melayu yang ekonominya rendah bekerja pada orang Tionghoa sebagai karyawan toko atau buruh bangunan. Selain perdagangan, interaksi antara etnis Tionghoa dan Melayu juga mencakup kemitraan dalam membuka tambang inkonvensional (TI). Biasanya orang Tionghoa yang menyediakan sarana dan prasarananya, sedangkan orang Melayu yang menjadi pekerjanya. TI banyak terdapat di Pemali, Sempang, Bintet (Belinyu).

Masyarakat Tionghoa yang umumnya pedagang memiliki peran penting dalam ketersediaan bahan maupun alat-alat yang diperlukan dalam kehidupan sehari-hari. Toko- 
toko di Sungailiat menyediakan berbagai macam peralatan maupun bahan-bahan yang diperlukan. Mayoritas pemilik toko adalah orang-orang Tionghoa dan etnis Melayu tidak pernah mempermasalahkan hal itu. Walaupun banyak etnis Tionghoa yang menjadi pedagang, namun tidak mengurangi minat beli orang Melayu.

Hubungan interaksi etnis Tionghoa dan Melayu terlihat pula dalam bidang politik. Orang Tionghoa memiliki kesempatan yang luas dalam berpartisipasi pada kancah politik. Menurut pengamatan penulis, etnis Tionghoa memiliki kesempatan yang sama dalam berpolitik. Selama ini orang Tionghoa terlihat kurang terlibat langsung dalam kegiatan politik karena mereka menyalurkan aspirasi berpolitik hanya sebagai pemilih dalam pelaksanaan pemilu. Namun saat ini sudah banyak orang Tionghoa yang menduduki jabatan sebagai anggota dewan. Anggota DPRD Kabupaten Bangka tahun 2008- 2013 tercatat ada 2 orang, yaitu Ir. Agung Setiawan, MM dan Riniarti Sajuni. Sedangkan di periode selanjutnya pada tahun 2013-2018 tercatat ada 4 orang etnis Tionghoa yang menduduki jabatan sebagai anggota dewan, yaitu Riniati Sajuni, Budiono, SIP, Junaidi Surya, dan Tjindriajana, SH.

Etnis Melayu lebih dominan dalam kancah perpolitikan karena tidak begitu banyak etnis Tionghoa yang yang berminat terjun ke kancah politik. Etnis Melayu memanfaatkan silsilah keluarga untuk memperoleh dukungan dari orang-orang saat mereka mengajukan diri sebagai orang yang akan dipilih dalam pemilihan, baik pemilihan kepala daerah maupun pemilihan anggota dewan daerah.

Interaksi etnis Tionghoa dan Melayu dalam masalah keagamaan cukup menarik. Hal ini terlihat dari kuatnya kerukunan yang tercipta sejak dahulu. Berdasarkan pengamatan penulis, kerukunan antar umat beragama terjalin dengan sangat baik. Tidak hanya antar pemeluk agama Islam dan Kong $\mathrm{Hu} \mathrm{Cu}$ saja, namun juga kerukunan umat ada dalam pemeluk agama Nasrani, Budha, maupun Hindu. Pada hari besar keagamaan, sangat terlihat bagaimana masyarakat sangat toleransi kepada pemeluk agama lain. Perayaan hari besar keagamaan tidak hanya disambut antusias oleh penganutnya, namun juga oleh penganut agama lain. Kerukunan antar umat beragama pada masyarakat Bangka terlihat dari kebebasan umat untuk beribadah, saling memberikan selamat dan bersilaturahmi saat hari besar keagamaan, Forum Kerukunan Umat Beragama Kabupaten Bangka yang berjalan dengan baik, dan terselenggaranya penggalangan dana untuk pembuatan rumah ibadah.

Bagi umat Islam, hari besar keagamaan dilaksanakan di hari Idul Fitri, Idul Adha, dan Tahun baru Islam. Bagi umat Nasrani, hari besar keagamaan dilaksanakan pada saat Natal dan tahun baru, bagi orang Tionghoa (agama apapun) hari besar yang dilaksanakan saat imlek. Pada hari-hari tersebut, umat yang merayakan akan mengadakan open house, menyediakan berbagai macam makanan dan minuman yang biasa disajikan di hari raya. Orang-orang akan datang untuk bersilaturahmi dan mengucapkan selamat. Khusus di daerah yang didiami oleh etnis Tionghoa seperti Rebo, Tong Hin, Pohen, dan Bintet, siswa-siswa diberikan izin khusus untuk tidak hadir di sekolah saat melaksanakan sembahyang rebut, merayakan ceng beng, dan imlek. Bahkan tak jarang guru-guru dan orang Melayu diundang oleh wali murid pada saat merayakan imlek.

Interaksi sosial antar etnis Tionghoa dan Melayu dalam bidang pendidikan dapat dilihat dari tidak adanya diskriminasi terhadap salah satu etnis untuk menempuh pendidikan. Beberapa informan mengatakan tidak ada perbedaan dalam menyikapi etnis Tionghoa dan Melayu dalam proses pembelajaran di kelas. Semua siswa diperlakukan sama, walaupun siswa bersekolah di sekolah yayasan, misalnya yayasan Setia Budi khusus untuk siswa etnis 
Tionghoa. Masyarakat Sungailiat bisa mendapatkan pendidikan sesuai dengan apa yang mereka harapkan, tergantung dengan dukungan orang tua siswa dan kemampuan ekonomi yang mereka miliki. Baik etnis Tionghoa maupun Melayu sama-sama memiliki kesempatan untuk mendapatkan pendidikan yang layak, karena saat ini sudah ada bantuan dana BOS dari pemerintah untuk anak-anak bersekolah.

Sarana pendidikan yang ada di Sungailiat cukup baik dan memadai bagi semua kalangan masyarakat. Pemerintah memberikan dukungan terhadap kemajuan pendidikan dengan cara memberikan bantuan beasiswa kepada siswa yang kurang mampu. Selain itu pemerintah juga memfasilitasi siswa yang berprestasi dengan memberikan bantuan dana untuk menunjang prestasinya.

Pendidikan sebagai modal untuk anakanak melanjutkan masa depan. Orang tua etnis Tionghoa menyekolahkan anak-anaknya di sekolah swasta untuk memberikan pengayaan pengetahuan keagamaan, karena sekolah swasta atau yayasan tidak dikelola pemerintah sehingga agama yang diajarkanpun disesuaikan dengan tujuan sekolah tersebut. Namun begitu tetap ada etnis Melayu yang bersekolah di sekolah swasta dengan alasan tidak diterima di sekolah negeri karena nilai yang kurang cukup dan lokasi sekolah yang dekat dengan rumah.

Interaksi sosial etnis Tionghoa dan Melayu juga terjadi dalam hal sosialkemasyarakatan. Jauhari dan Sugiri menyatakan bahwa masyarakat etnis Tionghoa yang merupakan etnis minoritas tidak menghalangi mereka untuk berpartisipasi dalam kegiatan sosial kemasyarakatan. Etnis Tionghoa menggunakan istilah-istilah kekerabatan, penyebutan nama saja (tanpa menyertakan istilah-istilah kekerabatan) untuk mengekspresikan kesantunan positif (2012, hlm. 114).Kegiatan amal yang dilakukan oleh etnis Tionghoa setiap tahun adalah saat menyelenggarakan kegiatan sembahyang rebut.
Sembahyang rebut merupakan ritual keagamaan etnis Tionghoa yang acaranya berupa pembagian makanan, bahan sembako dan uang yang akan diperebutkan setelah acara sembahyang selesai. Selain memberikan amal kepada orang Tionghoa atau Kong $\mathrm{Hu} \mathrm{Cu}$, mereka juga mmbagikan kepada masyarakat sekitar yang kurang mampu, begitu pula kepada orang-orang pendatang yang biasanya bekerja sebagai buruh bangunan atau buruh tambang.

Pemerintah Kabupaten Bangka memberikan dukungan penuh kepada etnis Tionghoa untuk terlibat dalam kegiatan kemasyarakatan. Pemerintah juga melibatkan etnis Tionghoa dalam acara-acara bakti sosial. Masyarakat Tionghoa Pemali adalah memiliki iuran bulanan untuk mengurus kematian warga Pemali, baik itu muslim atau bukan. Selain itu setiap masyarakat melaksanakan resepsi pernikahan, baik etnis Tionghoa maupun Melayu akan diundang. Selain itu pada perayaan hari besar keagamaan seluruh masyarakat Sungailiat Bangka ikut memeriahkan dengan suka cita.

Kemasyarakatan etnis Tionghoa dan Melayu terlibat dalam kegiatan gotong-royong membersihkan lingkungan, ikut serta dalam siskamling (sistem keamanan lingkungan), acara kematian, undangan resepsi pernikahan dan acara bakti sosial. Pertemanan atau ikatan persaudaraan antara etnis Tionghoa dan Melayu tercipta dikarenakan tempat tinggal mereka yang berdekatan dan tingkat ekonomi mereka juga setara. Karena sering bertemu karena rumah yang berdekatan, tentu akan kenal dan berkomunikasi. Orang Tionghoa dan Melayu berteman akrab sama seperti orang sesama etnis yang mencari sahabat karena mereka merasa serasi,dapat dikarenakan persamaan hobi atau persamaan lingkungan tempat tinggal, begitu pula dengan etnis Tionghoa yang bersahabat akrab dengan etnis Melayu, mereka tidak memperhatikan asal etnis, namun lebih kepada kecocokan mereka dalam berkomunikasi. 
Berdasarkan studi dokumen, strategi interaksi sosial antara etnis Tionghoa dan Melayu Bangka dilakukan dengan tidak ada dari kedua etnis tersebut yang menganggap salah satunya yang paling baik, tidak ada diskriminasi dalam pergaulan sehari-hari. Baik etnis Tionghoa dan Melayu diperlakukan sama, tidak ada keistimewaan untuk salah satu etnis tersebut. Selain itu, etnis Tionghoa sebagai etnis minoritas ikut dilibatkan dalam berbagai kegiatan kemasyarakatan. Beberapa bentuk kegiatan interaksi yang terjadi antara etnis Tionghoa dan Melayu adalah Imlek Ceria yang dilaksanakan untuk merayakan Imlek oleh masyarakat Sungailiat sebagai salah satu upaya menjaga solidaritas dan kerukunan antara etnis Tionghoa dan melayu Bangka.

Imlek Ceria diselenggarakan pada tanggal 25-28 Februari 2015 di desa Rebo. Imlek Ceria diselenggarakan oleh Dinas Kebudayaan dan Pariwisata Kabupaten Bangka yang bekerja sama dengan masyarakat Kabupaten Bangka khususnya masyarakat desa Rebo. Acara ini dibuka oleh Bupati Kabupaten Bangka dan berlangsung dengan meriah. Imlek Ceria menampilkan kesenian yang bernuansa Melayu dan Tionghoa. Seni yang ditampilkan antara lain Barongsai, tarian Melayu, tarian Tionghoa, Gambus, dan perlombaan-perlombaan yang dapat diikuti oleh seluruh masyarakat Sungailiat berdasarkan kategori yang dilombakan. Ada beberapa perlombaan yang dilombakan, antara lain lomba tari, lomba menyanyi, lomba seni Barongsai, lomba seni Gambus, lomba busana daerah, dan lomba pantun.

Bagian ini akan membahas temuan hasil penelitian yang telah diuraikan tersebut dengan hasil penelitian terdahulu dan teori, serta peraturan yang berlaku mengenai masyarakat multietnis. Keinginan untuk memiliki identitas sosial yang positif dipandang sebagai motor psikologik penting di balik tindakan-tindakan individu dalam setiap interaksi sosial (Eriyanti, hlm. 2006). Srategi yang dilakukan oleh etnis
Tionghoa dan Melayu dalam interaksi sosial sosial terjadi di dalam berbagai bidang. Soekanto (1990, hlm. 431) menyatakan: "Sistem kemasyarakatan mencakup pelbagai bidang kehidupan yang merupakan subsistem, oleh karena menjadi bagian dari suatu kesatuan yang menyeluruh. Biasanya subsistem tersebut terdiri dari subsistem politik, subsistem ekonomi, subsistem sosial, subsistem budaya, subsistem pertahanan-keamanan, subsistem hukum"

Ada beberapa faktor yang membuat strategi masyarakat etnis Tionghoa dan Melayu Bangka berjalan dengan lancar. Berikut penjelasan interaksi etnis Tionghoa dan Melayu Bangka dalam berbagai bidang.

\section{Interaksi Sosial Etnis Tionghoa dan Melayu Bangka Di Bidang Ekonomi}

Masyarakat etnis Tionghoa dan Melayu Bangka melakukan interaksi dalam bidang ekonomi. Masyarakat Bangka secara keseluruhan memiliki berbagai macam mata pencaharian, antara lain Pegawai Negeri Sipil, karyawan PT Timah, bisnis-perdagangan, peternak, berkebun, jasa, buruh (buruh tambang swasta dan buruh bangunan), dan nelayan. Sungailiat sebagai ibukota kabupaten termasuk sebagai kota dengan aktivitas perekonomian yang tinggi setelah Pangkal Pinang. Sepanjang jalan di kota Sungailiat dari ujung Parit Padang hingga ke Air Anyut merupakan pusat perekonomian di Sungailiat. Ruko-ruko yang tersebar di hampir sepanjang jalan dimiliki oleh hampir sebagian besar orang Tionghoa. Kalaupun ada ruko ataupun toko-toko milik orang Melayu hanya beberapa orang saja.

Orang Melayu yang berprofesi sebagai pedagang biasanya hanya pedagang kecil saja, misalnya pedagang sayur keliling, pedagang buah, pedagang ikan, ataupun pedagang kelontong yang tokonya berada di depan rumahnya, bukan di deretan ruko-ruko sepanjang jalan utama ataupun di pasar. Hampir sebagian orang Melayu menjadi PNS, karyawan 
swasta, pedagang kecil, dan buruh. Perempuan etnis Melayu yang tingkat pendidikannya rendah biasanya bekerja sebagai penjaga toko milik orang Tionghoa.

Semenjak tahun 2000, tambang inkonvensional mulai marak di Bangka. Bangka adalah pulau penghasil timah, oleh karena itu tidak mengherankan jika timah yang selama ini dikelola oleh PT Timah, akhirnya dikelola sendiri oleh masyarakat, bahkan ada beberapa tanpa mendapatkan izin dari PT Timah ataupun pemerintah. Karena timah menghasilkan keuntungan yang besar, maka banyak masyarakat yang tergiur dan kemudian membuka lahan untuk tambang inkonvensional. Membuka tambang inkonvensional harus mendapatkan izin dari pemerintah maupun PT Timah. Namun, tetap ada pihak masyarakat yang membuka lahan untuk tambang inkonvensional tanpa seizin masyarakat dan PT Timah. Akibatnya, banyak kerusakan lingkungan yang disebabkan karena lahan tambang inkonvensional. Bekas pertambangan timah meninggalkan lubang-lubang besar yang gersang dan merusak kejernihan air. Maka dari tambang inkonvensional dengan izinpun saat ini tidak diperbolehkan lagi. Selain karena berdampak tidak baik terhadap lingkungan, pemerintah ingin menjaga persediaan timah sebagai sumber daya yang tidak dapat diperbaharui.

Masyarakat etnis Tionghoa di Sungailiat mayoritas berprofesi sebagai pedagang. Orang Tionghoa yang berdomisili di Sungailiat biasanya adalah pedagang besar dan memiliki tingkat ekonomi menengah ke atas. Sedangkan etnis Tionghoa yang berdomisili di luar Sungailiat, atau daerah pedesaan banyak yang bermata pencaharian sebagai petani sayur dan rempah (lada), peternak (babi, unggas), buruh bangunan atau tambang inkonvensional, dan penjual hasil laut (ikan, cumi, udang, tiram, rumput laut, dan ketam/kepiting).

Karena hampir sebagian besar pedagang di pasar dan sepanjang jalan utama di Sungailiat adalah etnis Tionghoa, maka untuk membeli keperluan sehari-hari etnis Melayu dan masyarakat Bangka umumnya akan bertransaksi dengan etnis Tionghoa. Tentunya dengan berdagang dan memiliki pembeli tetap akan mendatangkan keuntungan bagi pedagang, yakni orang Tionghoa. Namun hal itu tidak pernah menjadi permasalahan bagi etnis Melayu. Pada dasarnya mata pencaharian etnis Tionghoa dan Melayu di Bangka hampir sama. Meskipun mayoritas etnis Melayu menjadi pegawai negara dan mayoritas etnis Tionghoa menjadi pedagang dan menguasai perdagangan di Sungailiat, namun dikarenakan tingkat ekonomi etnis Tionghoa dan Melayu di Kabupaten Bangka relatif setara, maka tidak ada kesenjangan sosial yang timbul di masyarakat. Hal ini menjadikan salah satu faktor baiknya interaksi antara masyarakat etnis Tionghoa dan Melayu Bangka dalam bidang ekonomi.

\section{Interaksi Sosial Etnis Tionghoa dan Melayu Bangka Di Bidang Politik}

Semenjak kepemimpinan Abdurrachman Wahid sebagai presiden, masyarakat Tionghoa semakin berani untuk berpartisipasi aktif dalam politik. ejala komunikasi politik sendiri bisa dilihat darii dua arah, yang p€rtama: bagaimana institusi-institusi negara yang bersifat formal atau suprastruktur politik menyampaikan pesanpesan politik kepada publik, yang kedua: bagaimana struktur politik merespons dan mengartikulasikan pesan-pesan politik terhadap suprastruktur (2008, hlm. 70). Memasuki pemilihan umum di tahun 2008, masyarakat etnis Tionghoa di Bangka mulai menjadi partisipan aktif, dengan mencalonkan diri sebagai calon terpilih. Tercatat pada pemilu tahun 2008-2013 ada dua orang anggota DPRD Kabupaten Bangka yang merupakan etnis Tionghoa, yaitu Ir. Agung Setiawan, MM dan Riniati Sajuni. Pada pemilu tahun 2013-2018 anggota DPRD Kabupaten Bangka yang merupakan etnis Tionghoa bertambah menjadi 
empat orang, yaitu Riniati Sajuni, Budiono, SP, Junaidi Surya, dan Tjindriajana, SH. Ada kenaikan jumlah anggota dewan terpilih yang menduduki DPRD Kabupaten Bangka.

Sementara itu, orang Melayu memang lebih dominan dalam partisipasinya dalam kancah politik. Mereka lebih terlihat dalam keterlibatan langsung dalam bidang politik, misalnya saja menjadi tim sukses salah satu partai atau salah satu kandidat yang akan dipilih dan menjadi salah satu calon terpilih. Dilihat dari hasil pada pemilu tahun 2008, etnis Melayu mendominasi daftar nama-nama calon legislatif, meskipun ada beberapa nama etnis Tionghoa yang masuk ke dalam daftar calon legislatif dan hasilnya ada juga etnis Tionghoa yang menadi anggota legislatif.

Partisipasi dalam bidang politik etnis Tionghoa sebetulnya sudah lama ada di Bangka, namun karena jumlah mereka lebih sedikit dibandingkan etnis Melayu, jadi tidak tampak. Etnis Tionghoa dan Melayu memiliki kesempatan sama dalam berpolitik. Terbukti semakin banyak etnis Tionghoa menjadi anggota legislatif. Tidak ada diskriminasi etnis minoritas oleh etnis mayoritas.

Partisipasi etnis Tionghoa semakin tampak terlihat setelah pengesahan RUU Kewarganegaraan menjadi Undang-Undang Kewarganegaraan pada tanggal 11 Juli 2006. UU ini memberikan keleluasaan bagi warga keturunan untuk berpolitik. Pemerintah Indonesia juga telah menetapkan adanya Kantor Kesatuan Bangsa, Perlindungan Masyarakat dan Politik berdasarkan PP Nomor 38 Tahun 2007 tentang Pembagian Urusan Pemerintahan, Pemerintahan Daerah Propinsi dan Pemerintah Kabupaten/Kota. Kantor Kesatuan Bangsa, Perlindungan Masyarakat dan Politik dalam Pasal 3 memiliki fungsi sebagai berikut: 1) Perumusan kebijakan teknis di bidang Kesatuan Bangsa, Perlindungan masyarakat, dan Politik;

2) Pemberian dukungan atas penyelenggaraan Pemerintahan Daerah di Bidang Kesatuan
Bangsa, Perlindungan masyarakat, dan Politik; 3) Pembinaan dan pelaksanaan tugas di bidang Kesatuan Bangsa, Perlindungan masyarakat, dan Politik; 4) Pelaksanaan tugas lain yang diberikan oleh Bupati sesuai dengan tugas di bidang Kesatuan Bangsa, Perlindungan masyarakat, dan Politik.

Lahirnya UU No. 12 Tahun 2006 tentang Kewarganegaraan dan UU No. 40 Tahun 2008 Tentang Penghapusan Diskriminasi Ras dan Etnis adalah landasan dari upaya dan komitmen pemerintah untuk memberikan perlindungan, kepastian, dan kesamaan kedudukan di dalam hukum pada semua warga negara untuk hidup bebas dari diskriminasi ras dan etnis. Dengan adanya Undang-Undang ini jaminan untuk etnis Tionghoa turunan semakin besar untuk terlibat dalam berbagai bidang di masyarakat.

\section{Interaksi Sosial Etnis Tionghoa dan Melayu Bangka Di Bidang Agama}

Di Sungailiat, terdapat beberapa agama yang diakui, yaitu Islam, Nasrani, Budha, dan Kong $\mathrm{Hu} \mathrm{Cu}$. Orang Melayu Bangka mayoritas adalah muslim. Melayu muslim menyebar di berbagai wilayah di kota Sungailiat. Hal ini dapat dilihat dari bangunan rumah ibadah yang bisa dijumpai di berbagai wilayah ini. Agama mayoritas kedua yang dianut oleh masyarakat Sungailiat adalah Kong $\mathrm{Hu} \mathrm{Cu}$ dan Budha.

Islam sebagai agama mayoritas memiliki peranan penting dalam interaksi sosial antar etnis. Menurut beberapa informan agama Islam sebagai agama mayoritas memberikan dampak positif bagi interaksi kedua etnis. Islam menganggap perbedaan sebagai Sunnatullah, sehingga umat Islam dapat lebih menerima dengan baik perbedaan dibandingkan dengan agama lain. Hal ini mendukung teori yang dikemukakan Idi (2012, hlm. 16) bahwa Islam salah satu elemen penting dari penganut agama mayoritas dalam bangsa pluralitas ini, memiliki peran dan fungsi signifikan dan strategis sebagai "perekat" integrasi sosial dan integrasi bangsa. 
Orang Melayu memberikan toleransi yang tinggi kepada agama lain, sehingga kedamaian yang diciptakan oleh orang muslim mempengaruhi pola pikir orang non muslim untuk menghargai atau toleransi dengan orang yang berbeda agama. Orang Melayu Bangka yang mayoritas muslim memang mengikuti ajaran Islam yang universal dan cinta damai sehingga mereka cenderung menerima pendatang dengan prasangka baik (huznuzon). Orang muslim juga tidak menyukai suuzhon (berburuk sangka) kepada siapapun atau apapun, sehingga orang muslim memiliki sifat tulus.

Etnis Tionghoa menganggap agama Islam sebagai agama alternatif yang baik, maka tidak mengherankan apabila etnis Tionghoa ada yang menjadi mualaf, baik karena keinginan dari diri sendiri (hidayah) maupun karena pernikahan. Etnis Tionghoa cenderung tidak menganggap pernikahan antar etnis dan menjadi mualaf sebagai hal yang tidak pantas, karena pernikahan antar etnis dan menjadi mualaf telah terjadi sejak dulu, sejak leluhur etnis Tionghoa datang ke Bangka.

Berbicara mengenai masalah agama, kerukunan umat beragama di Bangka sudah terjadi sejak abad ke 18 saat kedatangan etnis Tionghoa ke Bangka untuk menjad buruh tambang. Berdasarkan data dari beberapa informan, kerukunan umat beragama ini dikarenakan sikap saling menghormati, toleransi, dan kerjasama sesuai dengan pedoman masyarakat Bangka "sepintu sedulang". Sikap saling menghormati, toleransi dan bekerja sama merupakan warisan leluhur yang tetap terjaga hingga saat ini.

Para pemuka agama dalam menyampaikan ajaran agama atau berdakwah memperhatikan kontens yang akan diberikan karena Sungailiat sendiri adalah daerah yang pemeluk agamanya bermacam-macam. Tidak diperbolahkan bagi pemuka agama untuk menjelek-jelekkan salah satu agama dan mengganggu kerukunan umat beragama di Bangka. Komunikasi yang terjalin diantara pemeluk agama terjalin dengan baik, terbukti dengan adanya dialaog antar umat beragama dalam Forum Kerukuna Umat Beragama Kabupaten Bangka setahun sekali.

FKUB kabupaten kota mempunyai tugas sebagai berikut: 1) Memelihara ketentraman dan ketertiban masyarakat termasuk memfasilitasi terwujudnya kerukunan umat beragama di kabupaten/kota; 2) Mengkoordinasikan kegiatan instansi vertikal di kabupaten/kota dalam pemeliharaan kerukunan umat beragama; 3) Menumbuhkembangkan keharmonisan saling penegrtian, saling menghormati, dan saling percaya diantara umat beragama; 4) Membina dan mengkoordinasikan lurah dan kepala desa dalam penyelenggaraan pemerintah di daerah di bidang ketentraman dan ketertiban masyarakat dalam kehidupan beragama; 5) Menertibkan IMB rumah ibadat.

Kerukunan umat beragama di Bangka dapat terjaga karena masing-masing umat beragama diberikan kebebasan dalam melaksanakan ibadah, kebebasan untuk memeluk suatu agama tanpa paksaan, dan dukungan dari pemeluk agama lain saat merayakan hari besar keagamaan.

\section{Interaksi Sosial Etnis Tionghoa dan Melayu Bangka Di Bidang Pendidikan}

Pendidikan merupakan salah satu faktor penting yang berpengaruh besar bagi masa depan seseorang. Oleh sebab itu, pendidikan sangat diperlukan. Bagi masyarakat Sungailiat pendidikan merupakan hal yang penting, oleh sebab itu masyarakat Sungailiat menyekolahkan anak-anaknya minimal hingga SMA. Etnis Tionghoa dan Melayu memiliki kesempatan yang sama besar untuk mendapatkan pendidikan. Amy Gutman (Idi, 2009, hlm. 209) mengatakan bahwa dalam berdemokrasi setidaknya ada dua elemen penting, yakni sikap nondiskriminatif dan sikap nonprogresif. Sikap non diskriminatif berarti tidak membedakan perlakuan terhadap orang atau kelompok lain 
karena perbedaan etnis, agama, ras, keadaan ekonomi, gender, dan lain-lain. Setiap orang harus diperlakukan sama dalam memperoleh kesempatan pendidikan. Sikap nonprogresif berarti orang atau lembaga tidak menndas dan menekan orang atau kelompok lain demi kepentingan mereka.

Berdasarkan data, masyarakat etnis Melayu banyak yang menyekolahkan anaknya di sekolah negeri. Tujuan utamanya karena sekolah negeri memberikan pengajaran agama Islam sebagai salah satu mata pelajaran yang wajib diberikan kepada siswanya. Namun ada juga siswa muslim yang bersekolah di sekolah selain milik pemerintah, biasanya karena alasan jarak rumah yang dekat atau saat mendaftar di sekolah negeri nilai siswa itu tidak mencapai target minimal yang dikeluarkan sekolah.

Etnis Tionghoa cenderung menyekolahkan anaknya di sekolah swasta pada tingkat SD dengan alasan untuk mendapatkan pengayaan nilai-nilai agama yang mereka anut. Namun tidak semua etnis ini menyekolahkan anak-anak mereka di sekolah swasta, karena ada pula yang berpendapat bahwa sekolah negeri lebih bagus mutunya dibanding dengan sekolah swasta.

Masyarakat Sungailiat yang memiliki ekonomi menengah ke atas menyekolahkan anaknya di sekolah umum dan akan melanjutkannya ke bangku perkuliahan. Bangka sendiri memiliki universitas negeri yang terakreditasi yaitu Universitas Bangka Belitung (UBB), selain itu ada Politehnik Manufaktur Timah (Polman), Pertiba, Akademik Kebidanan dan keperawatan. Siswa yang berminat untuk melanjutkan kuliah di Bangka biasanya bukan dari Sungailiat ataupun Pangkal Pinang, tetapi dari daerah Bakam, Puding, Belinyu, Mentok, dan sekitarnya.

Masyarakat etnis Tionghoa yang memiliki ekonomi menengah ke bawah biasanya menyekolahkan anaknya di sekilah kejuruan seperti SMK, karena sekolah kejuruan akan memberikan keterampilan khusus bagi siswanya yang ingin langsung bekerja setelah menamatkan seklah menengah atas. Faktor ekonomi masyarakat Sungailiat sangat mempengaruhi sekolah yang akan dipilih oleh anak-anak mereka. Namun meski demikian, di setiap jenjang pendidikan baik swasta maupun negeri, baik umum maupun kejuruan umumnya terdapat anak-anak etnis Tionghoa dan Melayu.

Anak-anak multi etnis ini tidak memiliki hambatan sama sekali dalam berinteraksi karena mereka menggunakan bahasa daerah yang sama, yakni bahas Melayu. Dalam memilih teman untuk bergaul tidak ada diskriminasi terhadap etnis minoritas. Hal ini terlihat dari membaurnya anak-anak etnis Tionghoa dalam bergaul dengan anak-anak etnis Melayu. Sekolah menjadi sarana bagi siswa untuk mendapat pengetahuan dan pergaulan, seperti yang diungkapkan pula oleh beberapa informan.

Di sekolah siswa mendapatkan pendidikan dan pengetahuan, bimbingan yang sesuai dengan bakat dan minat siswa, dan arahan bagi siswa untuk mencapai cita-citanya. Selain itu, sekolah dapat menjadi tempat anak-anak multi etnis untuk bersosialisasi. Tidak ada masalah baik di sekolah swasta maupun sekolah negeri, anak-anak multi etnis dapat bersosialisasi dan bergaul dengan baik karena tidak ada perbedaan saat memperlakukan siswa etnis Tionghoa maupun etnis Melayu.

\section{Interaksi Sosial Etnis Tionghoa dan Melayu Bangka Di Bidang Sosial-Kemasyarakatan}

Etnis Tionghoa dan Melayu banyak terlibat interaksi di berbagai bidang. Salah satunya adalah interaksi dalam sosial kemasyarakatan. Sebagai etnis minoritas, etnis Tionghoa menyesuaikan diri dengan etnis Melayu sebagai etnis mayoritas. Penyesuaian diri etnis Tionghoa kepada etnis Melayu telah berlangsung sejak lama semenjak kedatangan mereka ke pulau Bangka.

Setelah etnis Tionghoa menjadi penduduk Indonesia, mereka juga terlibat dalam kegiatan 
sosial-kemasyarakatan. Mereka terlibat dalam pergaulan di masyarakat, berteman dekat dengan etnis lain, terlibat dalam kegiatan bakti sosial, ikut serta dalam kegiatan siskamling (sistem keamanan lingkungan), perayaan hari besar keagamaan, undangan pernikahan, dan acara kematian. Hal ini mendukung teori Gillin dan Gillin ( Soekanto, 2003, hlm. 71) yang menyatakan bahwa akomodasi membuka jalan ke arah asimilasi. Dengan adanya proses asimilasi, para pihak lebih saling mengenal dan dengan timbulnya benih-benih toleransi mereka lebih mudah untuk saling mendekati.

Ada beberapa faktor yang etnis Tionghoa dapat berteman dekat dengan etnis Melayu, antara lain karena pemukiman, persamaan tempat kerja atau sekolah, dan persamaan agama. Sungailiat merupakan pusat kota yang pemukiman antara etnis Tionghoa dan Melayu telah bercampur. Kebanyakan orang Tionghoa yang tinggal di kompleks atau pemukiman elite adalah orang Tionghoa yang tingkat ekonominya menengah ke atas. Kesetaraan ekonomi antara etnis Tionghoa dan Melayu membuat tidak ada kesenjangan sosial yang menjadikan kehidupan bertetangga akur dan tentram. Persamaan tempat kerja dan sekolah juga membuat komunikasi dan interaksi antara etnis Tionghoa dan Melayu berjalan dengan baik. Selain itu bagi etnis Tionghoa yang sudah menjadi mualaf, beragama Islam lebih mudah untuk diterima di masyarakat.

Muslim menyatakan bahwa interaksi sosial yang terjadi secara dinamis dalam proses tawar menawar bisa mewujudkan perubahan tata nilai yang tampil sekedar sebagai pergeseran (shift) antar nilai, atau persengketaan (conflict) antar nilai atau bahkan dapat berupa benturan (clash) antar nilai tersebut. Apapun bentuk dan perwujudan dari permasalahan silang budaya, harus dapat dipandu dan dikendalikan, atau paling tidak diupayakan adanya mekanisme yang dapat menjembatani permasalahan (2013, hlm. 489). Berdasarkan teori-teori yang menunjang dan hasil observasi dan wawancara bahwa interaksi sosial yang terjadi pada etnis Tionghoa dan Melayu Bangka bahwa strategi yang dilakukan oleh kedua etnis adalah dengan menerapkan semboyan fan ngin, to ngin jit jong, yang berarti 'pribumi Melayu, dan Tionghoa semuanya sama dan setara' sehingga interaksi dapat berjalan dengan baik di berbagai bidang. Tidak ada diskriminasi terhadap etnis Tionghoa yang menjadi etnis minoritas. Interaksi sosial yang asimilatif itu terjadi secara natural dan relatif sempurna (natural and relatively full-assimilation) dipengaruhi oleh keadaan sosial dan ekonomi masyarakat Bangka (Idi, 2010, hlm. 371).Etnis Melayu yang merupakan etnis mayoritas bersikap terbuka, memiliki prasangka yang rendah dan mau merangkul etnis lain dalam pergaulan sehari-hari membuat interaksi antara etnis Melayu dan Tionghoa semakin erat. Selain itu, dukungan dari pemerintah Indonesia dengan mengeluarkan Undang-Undang Kewarganegaraan semakin membuka kesempatan bagi etnis turunan seperti etnis Tionghoa untuk mendapatkan hak dan kesempatan yang sama dalam kehidupan berbangsa dan bernegara.

\section{PENUTUP}

Masyarakat etnis Tionghoa dan Melayu memiliki semboyan yakni fan ngin, to ngin jit jong, yang berarti 'pribumi Melayu, dan Tionghoa turunan semuanya sama dan setara'. Karena itu, hubungan kekeluargaan antar warga Melayu dan Tionghoa di Bangka tidak secara kebetulan, tetapi karena merasa sebagai satu keluarga besar yang diawali oleh hubungan para leluhur hingga saat ini. Sikap menerima status etnis Tionghoa dan Melayu yang sederajat menciptakan harmonisasi dalam kehidupan bermasyarakat sehingga diskriminasi bahkan konflik yang melibatkan SARA tidak pernah terjadi di Kabupaten Bangka.

Semboyan fan ngin, to ngin jit jong menjadi strategi masyarakat etnis Tionghoa dan 
Melayu dalam berinteraksi. Adanya kesetaraan status antara etnis Tionghoa minoritas dan etnis Melayu mayoritas menyebabkan interaksi sosial di berbagai bidang berjalan dengan baik dan sebagai mana mestinya. Kesatuan yang selama ini telah terjalin dapat terus dipertahankan hingga saat ini.

Adapun rekomendasi penelitian sebagai berikut: 1) Pemerintah pusat dan Kabupaten Bangka: pemerintah sebagai penentu dan pengambil kebijakan harus mengayomi seluruh masyarakat, sehingga dalam mengambil suatu kebijakan pemerintah harus memperhatikan masyarakat yang bermacam-macam ras, agama, budaya, bahasa, maupun adat istiadat agar tidak ada pihak yang dirugikan atas kebijakan tersebut; 2) Masyarakat etnis Tionghoa dan Melayu Bangka: perlu adanya peningkatan stratergi dalam interaksi kedua etnis. Jika peningkatan strategi tidak dilakukan, maka hambatan interaksi sosial masyarakat etnis tionghoa dan melayu akan tetap ada; 3) Peneliti selanjutnya: menjadi masukan dalam mengkaji strategi interaksi sosial antara masyarakat multietnis.

\section{DAFTAR PUSTAKA}

Anshory, C. H. N .(2008). Neo Patriotisme. Yogyakarta: Lki Spelangi Aksara

Idi, Abdullah. (2009). Asimilasi Cina Melayu di Bangka. Yogyakarta : Tiara Wacana.

Idi, Abdullah. (2012). Interaksi Sosial "Natural-Asimilatif" antara Etnis Muslim Cina dan Melayu-Bangka. Thaqafiyyat. Volume 13 (2), 371.
Eriyanti, Fitri. (2006). Dinamika Posisi Identitas Etnis Tionghoa dalam Tinjauan Teori Identitas Sosial. Demokrasi. Volume V (1), 29.

Jauhari, Sugiri. (2012). Kesantunan Positif Dalam Masyarakat Etnis Tionghoa di Surakarta. Mozaik. Volume 12 (2), 114.

Maftuh, B dan Sapriya. (2005) "Pembelajaran PKn melalui pemetaan konsep". Jurnal Civicus. Vol 1, (5), 319-320.

Muslim, Asrul. (2013). Interaksi Sosial Dalam Masyarakat Multi Etnis. Diskurkus Islam. Volume 1 (3), 489.

Pangestuti, Sri. (2008). Komunikasi politik Etnis Tionghoa. Acta Diurna. Volume 5 (2), 70.

Revida, Erika. (2006). Interaksi Sosial Masyarakat Etnik Cina Dengan Pribumi Di Kota Medan Sumatra Utara. Harmoni Sosial. Volume I (1), 25-26.

Salim, Agus. (2006). Stratifikasi Etnik. Yogyakarta : Tiara Wacana.

Spradley, James. P. (2007). Metode Etnografi. Yogyakarta : Tiara Wacana.

Soekanto, Soerjono. (2003). Sosiologi Suatu Pengantar. Jakarta : Raja Grafindo Persada.

Supardan, Dadang. (2008). Peluang Pendidikan dan Hubungan Antar Etnik: perspektif pendidikan kritis-poskonialis. Jurnal Pendidikan Kewarganegaraan Volume 2. No. 1

Suryadinata, L.(2002). Negara Dan Etnis Tionghoa Kasus Indonesia. Jakarta: LP3ES

Widodo, Mardi. (2010). Pengintegrasian dan Perkembangan Isu-Isu Global ke dalam Materi Pembelajaran Pendidikan Kewarganegaraan dalam Kerangka Karakter Pendidikan Bangsa Indonesia. Prospektus. Volume VIII (2), 142. 